\title{
Benjamin Disraeli, Romantic Orientalist
}

\author{
IVAN DAVIDSON KALMAR
}

\author{
University of Toronto
}

Of Edward Said's many passions, Joseph Conrad was among the most persistent. That a Polish-English writer of nineteenth-century colonial fiction should be the hero of the author of Orientalism might challenge those, among both Said's friends and enemies, who misread his work as a condemnation of major Western writers and thinkers who shared their period's Eurocentric prejudice. Said fully recognized Conrad's "uncompromising Eurocentric vision," yet discovered in it, perhaps paradoxically, a "felt tension between what is intolerably there and a symmetrical compulsion to escape from it." ${ }^{1}$ With the passage of time, what speaks to us is not Conrad's prejudices, but the way his texts "brush up unstintingly against historical constraints."

This, in my mind, is also the right approach to take to Benjamin Disraeli's life and work. No one was a more potent imperialist than he, the expansionist prime minister of Britain at the Empire's "greatest" hour. No one was more of an orientalist, whether one takes the word in its traditional sense of "fascinated by the Orient" or in the revised sense, influenced by Said, of one who imagines the Orient in a manner that is embedded in the goals and practices of Western domination. Yet this imperialist felt a romantic kinship for Empire's distant subjects. For crucially, this orientalist was, in his eyes and those of many others, himself an Oriental.

Since Said's seminal book Orientalism (published in 1978), scholars have focused their attention on the ambivalences that underlie Western perceptions of the Orient. Homi Bhabha in particular has argued for various forms of ambivalence to be recognized as an essential feature of orientalism. Bhabha, who sees orientalism in psychoanalytical terms as a form of fetishism, considers a mix of attraction and repulsion to be a defining feature of orientalism and of all other instances of stereotyping the colonial Other. The nature of the colonial stereotype ranges, to him, from "the loved to the hated."

A further ambivalence is important in Disraeli's case. Orientalism was an ex-

1 Edward W. Said, Freud and the Non-European, with an Introduction by Christopher Bollas, and a Response by Jacqueline Rose (London and New York: Verso, 2003), 23, 26.

2 Homi K. Bhabha, "The Other Question: Stereotype, Discrimination and the Discourse of Colonialism," ch. 3 of The Location of Culture (London: Routledge, 1994), 79.

0010-4175/05/348-371 \$9.50 C 2005 Society for Comparative Study of Society and History 
ample of a "colonial discourse"; it was also a discourse about European Jews. ${ }^{3}$ Although recent scholarly literature has underestimated the importance of orientalism-about-the-Jews in the annals of orientalism as a whole, its empirical weight is so overwhelming that no thoughtful writer on orientalism could ignore it altogether. Said, indeed, went so far as to state that in Orientalism he was writing "the history of a strange, secret sharer of Western anti-Semitism" and called orientalism anti-Semitism's "Islamic branch." (The uninitiated should note that the "Orient" in recent writing on orientalism usually means Muslim North Africa and West Asia along with India, and rarely Japan or China.) ${ }^{4}$

Actually, there was nothing secret about discourses that saw the Jews as oriental: from the late eighteenth to the early twentieth centuries it was thought to be axiomatic that the Jews were, as Herder had put it, "the Asiatics of Europe." Nor were these discourses always anti-Jewish. Often they were, at least on the surface, romanticizations.

Before Said, it was actually the anti-oriental spirit of orientalist discourse that was a secret to most observers. Romantic fascination and often admiration were the characteristic tone of orientalist representation. ${ }^{5}$ This was so even more where Arabs were represented rather than Jews, in academic scholarship as well as literature and the arts. Nothing exemplifies this better than nineteenthcentury orientalist genre painting, best known for images of Muslim men prostrated on prayer rugs and of marble-white women in belly-dancing outfits reclining on a divan surrounded by sumptuous draperies, an incense burner, a water pipe, and coffee cups. There were countless imitations and reproductions of such gallery art in the form of the kitsch items that formed, between 1850 and 1950, the bulk of what has been called "commodity orientalism." Commodity orientalism was also in abundant evidence at the monumental world fairs where whimsical palaces with horseshoe arches and minarets often constituted the majority of the exhibits. The platitude, uttered countless times in contemporary descriptions of such objects, was that they recalled the "dream of the Thousand and One Nights."

Dreams are not well understood without analysis. Since Said and Bhabha, we are well able to see the desire for domination and the anxious fear of the Other that is hidden in the romantic dream. ${ }^{6}$ But as students of the romance novel have long argued, romantic fantasies can also have liberating potential. Jan-

\footnotetext{
${ }^{3}$ For a review of some of the growing literature on this subject see the editors' introductory essay and other chapters in Orientalism and the Jews, Ivan Davidson Kalmar and Derek J. Penslar, eds. (Hanover, N.H.: Brandeis University Press, 2004); Gil Anidjar, The Arab, the Jew: The History of the Enemy (Stanford, Calif.: Stanford University Press, 2003).

${ }^{4}$ Edward W. Said, Orientalism (New York: Vintage Books, 1979), 27-28.

5 I leave aside the vexing question of just what romanticism properly is, because it is too complex to be handled within the space available and especially because I believe that my remarks apply to romanticism however defined. On the specifically Jewish aspects of orientalism during the Romantic period, see Sheila A. Spector, British Romanticism and the Jews: History, Culture, Literature (New York: Palgrave, 2002).

${ }^{6}$ For example, Said, Orientalism, 52-53; Bhabha, "The Other Question," 78-79.
} 
ice Radway has shown that romance plots can be read to transcend the patriarchal assumptions that structure them. ${ }^{7}$ It is not unlikely that, similarly, romantic orientalism might challenge its own underlying opposition between Occident and Orient. "Oh, East is East and West is West," wrote Kipling, "and never the twain shall meet;" but read on and you find a story of male bonding between a tough English soldier and a very macho Asian chieftain for whom "there is neither East nor West." 8 Kipling's romanticism here is, it is true, thoroughly infused with patriarchal and imperialist assumptions. My point is emphatically not that orientalism is ever free of racism, but that in it racism is often inextricably mixed with elements that contain its negation. Orientalism has seldom been the kind of deliberate hate speech that many now imagine it to be, oversimplifying and misinterpreting Said's much more nuanced presentation. As in Conrad's case, it would be more precise to think of prejudice here as an underlying, omnipresent condition, often accompanied by "a symmetrical compulsion to escape from it."

\section{A CONSISTENTLY PROUD JEW}

Benjamin Disraeli, (1804-1881) was, it is being increasingly recognized, a character out of the annals of nineteenth-century romanticism. The romantic nineteenth century preferred vision to calculation and spectacle to deliberation. It had little use for philosopher-kings; a flamboyant writer-prime minister like Disraeli would do much better. He was not only the relentlessly imperialist politician who gained the Suez Canal and Cyprus for Britain and solidified British influence throughout the Orient at the expense of the French and the Russians. He was also a spinner of ostentatious fiction, novels of high society as well as tales of the Orient. Of the latter, Tancred or the New Crusade, first published in 1847 , is of primary interest in this essay. ${ }^{9}$

In the last twenty years or so there has been a re-evaluation of Disraeli among historians, focusing on "the role played in Disraeli's conception of life and politics by his Jewishness and his romanticism." ${ }^{10}$ My goal is to bring the twohis Jewishness and his romanticism - a little closer together under the rubric of orientalism, noting that his Jewishness was in his as well as his opponents' views thoroughly "oriental." With the notable exception of Patrick Brantlinger, most scholars involved in the Disraeli reappraisal have not yet given sufficient consideration to this fact. ${ }^{11}$

7 Janice Radway, Reading the Romance: Feminism and the Representation of Women in Popular Culture (Chapel Hill: University of North Carolina Press, 1984); and "Romance and the Work of Fantasy," in, Jon Cruz and Justin Lewis, eds., Viewing, Reading, Listening: Audiences and Cultural Reception (Boulder, Colo.: Westwood Press, 1994).

8 Rudyard Kipling, "The Ballad of East and West."

9 There have been a large number of subsequent reprintings and editions.

${ }_{10}$ Paul Smith, Disraeli: A Brief Life (New York: Cambridge University Press, 1996), i.

11 Patrick Brantlinger, "Disraeli and Orientalism," in, Charles Richmond and Paul Smith, eds., The Self-Fashioning of Disraeli, 1818-1851 (Cambridge, UK: Cambridge University Press, 1998), 
The romantic aspects of orientalism - as it pictured both Muslims and Jews - were pre-eminent in the self-image of modernizing western Jews from the late eighteenth century to the early twentieth. True, the potential for using the Jews' oriental roots in order to exclude them from the European polity was apparent from the start, as in Johann D. Michaelis' anti-Jewish tracts. ${ }^{12}$ And in general the symbolic exclusion, in romantic guise or otherwise, of the Jews from Western origins guaranteed that even the most "assimilated" Jew would be regarded by gentiles as "almost the same but not quite," the perennial condition, according to Bhabha, of the colonial who mimics the European. ${ }^{13}$ Even so, the apparently admiring side of romantic orientalism was at first more evident than its reverse, and it allowed many Jews to think of orientalism as holding potential for improving the image of their people among the Gentiles. Of particular relevance here was the quest in biblical criticism (one of the most potent intellectual adventures of the late eighteenth and the nineteenth centuries) ${ }^{14}$ to uncover the "true" life of Jesus among a people with alleged Semitic racial characteristics. ${ }^{15}$

The biblical critics and other orientalist scholars such as Ernest Renan often depicted Jesus as representing a marked contrast to his Semitic environment. ${ }^{16}$ Jews responded by, on the contrary, insisting that Jesus had been a typical Semite and Jew. The "Jewish Jesus" they created was an ideological mainstay of nineteenth- and early twentieth-century modernizing Jewry. ${ }^{17}$ One of them, Immanuel Deutsch (1829-1873), a German-born scholar active in Britain, greatly influenced George Eliot in her writing of Daniel Deronda (1876). The Jewish Jesus had a certain cachet among the Gentiles, and it was this that Disraeli as an author gambled on.

90-105; and "Nation and Novels: Disraeli, George Eliot, and Orientalism," Victorian Studies 35 (1992), 255-76. Among the works where Disraeli's ubiquitous "oriental" image is recognized is Bryan Cheyette's Construction of "the Jew” in English Literature and Society: Racial Representations, 1875-1945 (Cambridge, UK: Cambridge University Press, 1993). The only book-length treatment of Disraeli's Jewishness as an "oriental" one is, to my knowledge, a University of Bonn doctoral dissertation from 1930: Boris Segalowitsch, Benjamin Disraeli's Orientalismus (Berlin, 1930, publisher not given, available at the University of Toronto Robarts Research Library). This work is quite informative and should probably be discussed in any future attempt to write a monograph on the topic.

12 Jonathan M. Hess, Germans, Jews and the Claims of Modernity (New Haven: Yale University Press, 2002), ch. 2.

13 Bhabha, "Of Mimicry and Man: The Ambivalence of Colonial Discourse," ch. 4 of The Location of Culture, $86,89$.

14 See, in these pages, James Pasto, "Islam's 'Strange Secret Sharer': Orientalism, Judaism, and the Jewish Question," Comparative Studies of Society and History 40 (1998): 437-74.

15 For an interesting recent appraisal of biblical scholars' expeditions of discovery among the Bedouin, whom they considered to be an ossified Semitic people who still lived like the ancient Jews at the time of Jesus, see Jonathan Hess, Germans, Jews and the Claims of Modernity (New Haven, Conn.: Yale University Press, 2002), 51-90.

16 Ernest Renan, The Life of Jesus (New York: Modern Library, 1955), originally La vie de Jésus, first published in 1863 .

17 Susannah Heschel, Abraham Geiger and the Jewish Jesus (Chicago: University of Chicago Press, 1998). 
I am therefore at variance with Isaiah Berlin's assessment of Disraeli's Jewish-orientalist fantasies as a personal quirk motivated by career considerations: "the fact that he was born a Jew offered an obstacle to his career: he overcame it by inflating it into a tremendous claim of noble birth ..."18 Disraeli's "Semitic" identity was not an eccentric personal foible as much as a reflection of a widely held attitude towards the "Jewish race" and its history. Jewish pride in being oriental was no rarity. ${ }^{19}$ Disraeli espoused it with considerable and consistent passion.

If his enemies were to be believed, principle and consistency were not Disraeli's strength. The Globe sounded a familiar tune when it described him as "hunting with the hounds, and holding with the hare." ${ }^{20}$ Few of Disraeli's numerous biographers ${ }^{21}$ (with the exception of his semi-official chroniclers, Moneypenny and Buckle) seem to have put out a limb to rescue him from the accusation of inconsistency, either. ${ }^{22} \mathrm{He}$ has typically been described as an opportunistic careerist: he switched parties to get elected, he wrote his books only to pay his many bills, he got married for money, not love.

Yet friend and foe conceded that Disraeli was consistent on one point: his passionate pride in his Jewish "race," which he understood to be oriental and as he put it "Arabian." The explorer and public figure Wilfrid Scawen Blunt (who became a Muslim convert) considered Disraeli to be "a very complete farceur" who never "for an instant took himself seriously," but added that his "Semitic politics of course were genuine enough ..."23

18 Isaiah Berlin, "Benjamin Disraeli, Karl Marx, and the Search for Identity," in, Berlin's Against the Current: Essays in the History of Ideas, ed. by Henry Hardy (Oxford University Press, 1981), 252-86.

19 See Ivan Kalmar and Derek Penslar's introduction, and John Efron's chapter "Orientalism and the Jewish Historical Gaze," in Orientalism and the Jews; Ivan Davidson Kalmar, "Moorish Style: Orientalism, the Jews, and Synagogue Architecture," Jewish Social Studies: History, Culture, and Society 7, 3 (2001): 68-100.

20 The Globe, 20 Oct. 1885. Ann Potinger Saab, "Foreign Affairs and New Tories: Disraeli, 'The Press,' and the Crimean War, International History Review 19 (1997): 301.

${ }^{21}$ The classic biography is William Flavelle Moneypenny and George Earle Buckle's The Life of Benjamin Disraeli Earl of Beaconsfield (new and rev. ed., 4 vols., New York: Russell and Russell, 1968). Among recent books on Disraeli, one might mention Edgar J. Feuchtwanger, Disraeli (London: Arnold, 2000); Charles Richmond and Paul Smith, eds., The Self-Fashioning of Disraeli, 1818-1855 (New York: Cambridge University Press, 1998); Paul Smith, Disraeli: A Brief Life (New York: Cambridge University Press, 1996); Terence Andrew Jenkins, Disraeli and Victorian Conservativism (London: MacMillan, 1996); Jane Ridley, Young Disraeli, 1804-1846 (New York: Crown, 1995); Ian Machin, Disraeli (London: Longman, 1995); and Stanley Weintraub, Disraeli: A Biography (New York: Truman Talley Books, 1993).

22 One of the exceptions is Saab, who points out, correctly, that in addition to his Jewish and Semitic sentiments Disraeli showed great consistency in his support for the landed aristocracy and his belief in the importance of community and the individual's responsibility toward it. ("Foreign Affairs," 300.)

${ }^{23}$ Wilfrid Scawen Blunt, My Diaries: Being a Personal Narrative of Events 1888-1914, vol. 2 (New York: Knopf, 1921), 71-72. Edgar Feuchtwanger mentions a similar statement by W. E. Gladstone and others among Disraeli's enemies, who thought his Jewish pro-Semitism to be his only genuine feature (Edgar Feuchtwanger, "'Jew Feelings' and Realpolitik: Disraeli and the Making of Foreign and Imperial Policy," in, Todd M. Endelman and Tony Kushner, eds., Disraeli's Jewishness, London: Vallentine Mitchell, 2002, 183-85). 
My thesis is that Disraeli's vision of the Orient informed with remarkable consistency not only his personal identity and his fiction but also his policies as a public figure. To make the point, I look-after discussing only briefly Disraeli's personal Jewishness - at (1) Disraeli's early race theories, which he used to represent the Jews (and Arabs!) as a race given the exclusive privilege of speaking with God; (2) Disraeli's vision of "Tory Democracy," which would grant the vote to most English males; (3) Disraeli's advocacy of the British Empire as a commonwealth of "association" rather than "dependence," uniting East and West under British suzerainty; and (4) some of Disraeli's specific imperial policies such as his support for Turkey against Greece and Russia, but for Egyptian insurgents against Turkey. In all of these cases, I suggest, Disraeli comes across as a romantic orientalist who, often in the face of overwhelming opposition, hung on to his sincere if patronizing vision of a once glorious Orient made noble again and as a result ennobling the West.

\section{A JEW, AN ARAB, AND A CHRISTIAN}

In a letter from Jerusalem to his beloved sister Sarah, the twenty-seven-yearold Benjamin Disraeli described the Church of the Holy Sepulcher as coglioneria. $^{24}$ The Italian word may have been used in Judeo-Spanish, the intimate tongue of the Sephardic Jews, and is related to coglioni, meaning "testicles." Calling the site where Jesus is supposed to have been crucified a coglioneria is tantamount to calling it, in English, something worse than "a bloody fraud."

Of much more interest to the future prime minister was a sight sacred to Muslims and Jews, the haram ash-sharif or Temple Mount, which was at the time forbidden to non-Muslims. "I endeavored to enter it at the hazard of my life. I was detected and surrounded by a horde of turbaned fanatics, and escaped with difficulty," 25 recalled Disraeli, who had himself been wearing a turban as part of a Muslim disguise.

Disraeli loved cultural cross-dressing; more than once on his voyage to the Orient (in 1830-1831) he wore fancy dress. So when he was invited to dine with a Turkish pasha fighting the Greeks, his joy knew no bounds. "I am quite a Turk," Disraeli reminisced, "wear a turban, smoke a pipe six-feet long, and squat on a Divan. Mehemet Pacha told me that he did not think I was an Englishman because I walked so slow. In fact I find the habits of this calm and luxurious people entirely agree with my own preconceived opinions of propriety and enjoyment...." Like a twentieth-century anthropologist, when Disraeli smoked with the "natives" he clearly felt that he was a breed apart from other white men from the West.

In his case that was literally true. Eight days after Benjamin was born on 21 December 1804, he was no doubt circumcised in accordance with ancient Jew-

24 J.A.W. Gunn, J. Matthews, D. M. Schurman and M. G. Wiebe, eds., Benjamin Disraeli Letters (Toronto: University of Toronto, 1982), 1, 188, letter no. 110 to Sarah Disraeli, Alexandria, 20 Mar. 1831.

25 Disraeli, Alroy, n. 35. 
ish custom, his parents being regular members of the Bevis Marks Sephardic synagogue in London. But at the age close to thirteen, when a Jewish boy would have his bar mitzvah, Disraeli was, instead, allowed by his father to be baptized into the Anglican Church. That the conversion was not for sincere religious reasons is clear from the fact that his parents did not choose to get baptized as well. Theirs was a pragmatic decision recognizing that there was no future for their son in a country where Jews still enjoyed few civic rights. As a result of the ritual Disraeli became a defender of the established church, and probably a sincere Christian in his own idiosyncratic, Jewish-Christian way.

The extent to which Disraeli can be called a Jew has continued to occupy historians. ${ }^{26}$ Here I will simply note two indisputable facts. First, Disraeli was regarded by everyone as a Jew. There was, as Endelman and Kushner point out, a "popular perception that baptised Jews remained Jews." 27 Second, in Disraeli's own mind that perception was correct. Not that he maintained close ties to the organized English-Jewish community (he did very little for it throughout his life). ${ }^{28}$ But he saw his place in England and the world as one that was appropriate to a member of the "Arabian race" (i.e., the Jews) who brought the Western world its spiritual heritage. He never denied that he remained a Jew, though to him that did not preclude one from being a fine Christian at the same time.

Disraeli's thoughts on Jews and Christianity are laid out most clearly in Tancred. Here he gives no hint that he believes Judaism to be inferior to Christianity. It is true that Disraeli referred to Jesus as the "greater successor" of Moses. ${ }^{29}$ But to him what distinguished Jesus was not moral or spiritual innovation, and certainly not his divine character, as much as his public relations skills: Jesus was more effective than Moses in spreading the message God gave to the Jews. Disraeli makes Tancred, the young gentile Englishman, explain the way Jesus' greatness appears to him: “. . . through this last and greatest of [the Hebrew] princes it was ordained that the inspired Hebrew mind should mould and govern the world. Through Jesus, God spoke to the Gentiles, and not to the tribes of Israel only. That is the great worldly difference between Jesus and his inspired predecessors. Christianity is Judaism for the multitude, but still it is Judaism ..." ${ }^{30}$ The Jesus we meet here is a charismatic popularizer who managed to "package" Judaism for the Gentile masses. Through his efforts Judaism conquered the world: "Titus destroyed the Temple. The religion of Judea in turn subverted the fanes which were raised to his father and to himself in their im-

\footnotetext{
26 An indispensable tool for understanding this issue that brings together some of the best relevant work, is Endelman and Kushner's edited volume Disraeli's Jewishness, with a comprehensive introduction by the editors.

27 Endelman and Kushner, "Introduction," Disraeli's Jewishness, 3.

28 On this point see, for example, Bernard Glassman, Benjamin Disraeli: The Fabricated Jew in Myth and Memory (Lanham, MD: University Press of America, 2002).

29 Tancred, 203. 30 Tancred, 505.
} 
perial capital; and the God of Abraham, of Isaac, and of Jacob, is now worshipped before every altar in Rome." 31 This then is his superiority: Jesus created nothing really new but was better than Moses at spreading the Word. Disraeli's was an early version of the "Jewish Jesus" approach to Christianity that was mentioned earlier. It was a mixed compliment, acknowledging the greatness of Jesus but claiming that all he taught had been said before by the rabbis.

No wonder then, that when Tancred suggests to Eva, a "beautiful Jewess" he falls in love with, that she get baptized, her refusal is tactful but unequivocal: "In this perplexity it may be wise to remain within the pale of a church older than all of them, the church in which Jesus was born and which he never quitted, for he was born a Jew, lived a Jew, and died a Jew; as became a Prince of the house of David, which you do and must acknowledge him to have been. Your sacred genealogies prove the fact; and if you could not establish it, the whole fabric of your faith falls to the ground." ${ }^{32}$ How absurd it is to expect a Jew to become a Christian for other than worldly reasons is shown by the episode in Tancred of the overzealous Reverend Mr. Bernard and his ex-Jewish bishop, preaching in the Holy Land to some converts who passed themselves off as Jews. In fact, they turned out to belong to an old Christian tribe. ${ }^{33}$

Sometimes Disraeli's assertive Jewishness makes one wonder how he managed to get away with it. There is a famous apocryphal story that, when in 1835 O'Connell, the powerful Irish parliamentarian, attacked his Jewish ancestry, Disraeli replied without hesitation: "Yes, I am a Jew, and when the ancestors of the right honorable gentleman were brutal savages in an unknown island, mine were priests in the temple of Solomon." Though it may be untrue, the episode accords well with the spirit of Tancred, where Disraeli wrote of "some flatnosed Frank, full of bustle and puffed-up with self-conceit (a race spawned perhaps in the morasses of some Northern forest hardly yet cleared.)"34

How did Disraeli come by such chutzpah? According to a number of historians, Disraeli's Jewish identity developed on his voyage to the Orient. In Michael Polowetzky's words, "Disraeli was forever influenced by his experiences in the East. (...) He learned that he no longer had to think of himself merely in terms of being different from the other people he lived with; he was not required to define his personality only by what he was not. (...) Disraeli now finally embarked on a fascination with Judaism which would last for the rest of his life." 35

It is, however, difficult to confirm if Disraeli's Jewish sentiments changed in the Orient; at any rate, there is little indication in the record that they did. Where Polowetzky is certainly wrong is in the assumption that in the Orient Disraeli "learned" that he was not "different," that he was no longer among people who

31 Tancred, 199. ${ }^{32}$ Tancred, 225. ${ }^{33}$ Tancred, 569. ${ }^{34}$ Tancred, 233.

35 Michael Polowetzky, Victorian Intellectuals and the Birth of Modern Zionism (Westport, Conn.: Praeger, 1995), 34-35. 
were "what he was not." Nothing that happened to Disraeli in the Orient had the power of making him feel that he was among his own there, unless he had felt so in the first place. His letters to Sarah show that he felt little in common with either the "turbaned fanatics" or the Christians he encountered, and he had minimal contact with Middle Eastern Jews. His oft-quoted rapture with Jerusalem- "I was thunderstruck. I saw before me apparently a gorgeous city. . . Except Athens, I never saw anything more essentially striking. . . I I will not place it below the city of Minerva" 36 — need not and probably should not be read as testimony to a conversionary experience. ${ }^{37}$ It was not the Orient that he observed, but the imagined Orient that he carried with him as his guide, that excited a sense of belonging in him as he made his way to a Pasha's feast or the holy sites of Jerusalem.

Like many an orientalist voyage, Disraeli's trip was useful less in revealing new things to him than in giving him the legitimacy to rearticulate as an expert what everyone already "knew" about the Orient. In his case his expertise gained further legitimacy from the "fact" that he was an oriental himself.

As an alleged oriental, Disraeli was like other European Jews only more so: he belonged to the Sephardi denomination (a minority in Europe but the majority in the Middle East) whose practitioners are reckoned descendants of the Jews who had prospered in Muslim Portugal and Spain. It must have increased Disraeli's oriental cachet that he was able (in spite of his family roots in Italy) to claim descent from Muslim-ruled Iberia rather than the Christian regions of Central and Eastern Europe. His appearance only added to the exotic impression he made on the average Englishman: he had large dark eyes and his hair fell about his olive-colored face in large black, un-English curls. "A little black Jew, and a very Arab one," the phrase Jacques Derrida would use to describe himself, also applied to Disraeli. ${ }^{38}$ If the Jew in general was, in the Western imagination, almost white but not quite, Disraeli was even less white than the rest.

He was proud of the fact. Disraeli's brand of Christianity was not merely Judaizing, it was orientalizing. The decline of the Church of England was, in his mind, due mainly to "its deficiency of oriental knowledge." 39 The church, and the West in general, he argued in Tancred, must lose their spirit if they neglect "that oriental intellect to which they owed their civilization," that is, the spirit of Judaism. ${ }^{40}$ Tancred is a young English aristocrat who sets out, in search of religious revelation, on a pilgrimage to the Holy Land. He is convinced that divine revelation is "local." He comes to despair, however, if it may not also be

36 J. Gunn, et al., eds., Letters 1, 187-88, letter no. 110, Benjamin to Sarah Disraeli, Alexandria, 20 Mar. 1831.

37 Saab, "Foreign Affairs," 288, is not unusual in this respect.

38 Jacques Derrida, "Circumfession," in Geoffrey Bennington and Jacques Derrida, eds., Jacques Derrida (Chicago: University of Chicago Press, 1993), 58/F57.

39 Tancred, 83. ${ }^{40}$ Tancred, 202. 
racial: "Let men doubt of unicorns," Tancred is told by a "Jewish sheikh," "but of one thing there can be no doubt, that God never spoke except to an Arab."

It is not clear just to whom exactly Disraeli means to refer to as "Arab," but the personages he must have had in mind are-apart from the biblical Prophets-Moses, Jesus, and Muhammad. Jews, on this account, were Arabs and Arabs were Jews, both of them members of the "sacred race" to which Israelites as well as Ishmaelites belonged. Had Disraeli been able to look a hundred some-odd years ahead he would have been surprised at what a hot potato the Jewish-Arab connection would become. He showed no sign of the anguish that Derrida would experience when confronting the common heritage of the two peoples (which, it is true, was of more personal significance to the Algerian-born philosopher). "I have never yet been able to speak of what my birth, as one says, should have made closest to me: the Jew, the Arab," writes Derrida; and elsewhere (translating Wittgenstein) he adds, "Concerning that about which one cannot speak, isn't it best to remain silent?"42 But what Derrida labels the "explosive" substance of the "Abrahamic" kinship between Jew and Arab showed considerably fewer signs of combustibility before the beginning of significant Jewish emigration to Palestine. Disraeli's case teaches that explosions are caused, in texts as in real life, not as much by the tensions of the Abrahamic mysteries themselves as the political conflicts that they are made to articulate. To Disraeli they articulated a kinship and a common election by God.

Though Tancred had every reason to be frustrated at learning that God only spoke to "Arabs," an angel at last does speak to him on his trip to Mt. Sinai, possibly making him the first "Frank" to directly receive the word of God. This, however, happens only after Tancred thoroughly learns the lesson that religious inspiration is a racial peculiarity of the Orient, and in particular, of course, of one "Arabian tribe"- the Jews. And so the angels may yet speak again to England, if the English learn that their religion depends on inspiration from "Asia."

Thus enlightened, Tancred resolves, under divine inspiration, to fight for a union of "Asia" and England, which was to reinvigorate both. This is a different Tancred from his medieval namesake. It goes without saying that he is an imperialist who wants England to rule the Holy Land as it was its "destiny" to rule other parts of the Orient. One is reminded of Said's observation that formally "the orientalist sees himself as accomplishing the union of Orient and Occident, but mainly by reasserting the technological, political, and cultural supremacy of the West. ${ }^{43}$

However, Tancred's spiritual aim is not to make the Holy Land Christian but to make Christianity more oriental—read Jewish. His love for Eva, the beauti-

41 Tancred, 319.

42 Jacques Derrida, "How Not To Speak: Denials," Derrida and Negative Theology, ed. by Harold Coward and Toby Foshay (Albany: State University of New York Press, 1992), note 13.

${ }^{43}$ Edward W. Said, Orientalism (New York: Vintage Books, 1979), 246. 
ful philosophical Jewess, is symbolic. Eva is a personification of the virtues of her people, a sort of a Jewish equivalent to Lady Britannia or Marie France. The marriage of Tancred and Eva would be the marriage of England and Israel, of West and East. In Tancred's view his union with Eva would advance "the sovereign purpose of our lives: ... That Asia should regenerate itself to defend the Oriental Faith now challenged in the West." 44

Towards the end of Tancred the hero and Eva do get engaged. Whether or not their marriage actually takes place is left for us to ponder. Perhaps Disraeli felt that a marriage between a Christian nobleman and an unconverted Jewish woman would still be a bit hard for his public to digest. But he did make it clear that such a wedding was not only possible but desirable on religious, including Christian grounds. The Jews, the "Arabian tribe" that God spoke to, were a fine breed, indeed the best. In terms of lineage, Eva was in every way Tancred's match.

How could such cheek attract an English public that was permeated with antiJewish prejudice? The answer is that its appeal was that of one romantic nationalism to another. It was the appeal of the Jew, the giver of Eastern wisdom, to the English, leaders of the ascendant West. The pseudo-aristocracy that Disraeli attributed to the Jews was based on their status as the Chosen People. What he offered in no uncertain terms was an alliance of the Chosen People of the Bible with the Chosen People of modern Empire, the English - the marriage of Eva and Tancred. It was an offer that was ridiculed by many. But there were many takers as well.

\section{AN ORIENTAL JEW ATTRACTS ATTENTION}

In fact, Disraeli's pro-Semitic bravado was not only endured but in fact greatly enjoyed by much of the English public. Many of the biographies are fond of depicting a determined, dandified Benjamin Disraeli standing on the speaker's platform while people in the crowd yell "Ol' clo"" ("old clothes," the cry of a Jewish peddler). When Disraeli finally gets into Parliament and makes his maiden speech, he is forced by the catcalls and laughter to sit down and swears, "I will sit down now but the time will come when you will hear me." The Tory Prime Minister Peel refuses Disraeli a cabinet post.

All this, and more, is fact. ${ }^{45}$ Nor are the historians who attribute many of Disraeli's career failures to anti-Semitism being far-fetched. And yet: Disraeli was elected to Parliament, did become prime minister, and was the confidant of Queen Victoria who raised him to the peerage, in 1876, as the first Earl of Beaconsfield. Moreover, most of his books, including Tancred, sold very well in

44 Tancred, 575-76.

45 The extent of the antisemitic torment Disraeli had to endure is explored by two excellent articles in Endelman and Kushner, Disraeli's Jewishness: R. W. Davis, "Disraeli, the Rothschilds and Antisemitism”; and Anthony S. Wohl, “'Ben Juju:' Representations of Disraeli's Jewishness in the Victorian Political Cartoon." 
spite of some of the critics' anti-Semitic comments. It seems that everyone who read in England (that is, the nobility and the "educated classes") knew Disraeli's fiction, even if Disraeli may have exaggerated when he claimed that his Lothair was "more extensively read both by the people of the United Kingdom and the United States than any work that has appeared for the last half-century." 46 There were at least some aristocratic homes where his work was admired. He recalled an evening at the house of Countess Montalembert, who, as Disraeli saw it, lionized him and wanted him to entertain her high-born guests by reading from her copy of his Venetia. ${ }^{47}$ Even O'Connell, whose uncivil parliamentary exchange with Disraeli was mentioned earlier, knew his novels before he knew Disraeli himself. ${ }^{48}$ Mrs. Wyndham-Lewis, his future wife, described him well before their liaison as "one of our greatest writers." 49 Edgar Allen Poe gave both overt compliments to his work and plagiarized it extensively. ${ }^{50}$ Last but not least, one of his readers was the Queen, who commented, "Mr. Disraeli (alias Dizzy) writes various curious reports to me of the House of Commons proceedings much in the style of his books." 51

Is it so certain that Disraeli's advancement was entirely in spite of, rather than because of, his Jewishness? Disraeli published Alroy, a novel whose hero is a Jewish "king of the exile," as he was planning his first election campaign for Parliament. The story of the Jewish king represented, he said, his "ideal ambition." ${ }^{52}$ Why stress his Jewish pride before an electorate that, if most of the biographers are right, despised his Jewish background? According to Feuchtwanger, "Disraeli adopted attack as the best means of defense." Weintraub thinks that Disraeli was "taking the offensive in the matter of his origins." 53 Correct. He was certainly fond of Falstaff's suggestion that "A good wit will make use of anything; I will turn diseases to commodity." ${ }^{54}$ But what is also interesting is the manner in which Disraeli did turn Jewishness to his advantage. A politician with a physical defect might wish to draw attention to the will power it takes to be a leader in spite of his or her handicap; one accused of corruption or immorality might make a public excuse and demonstrate his or her victory over a past failing. But Disraeli never portrayed his Jewish origins as an impediment to overcome. He proudly presented them as an advantage.

Maybe he was right. By almost common consent, Disraeli owed his intro-

46 Preface to the "Hughenden" 1870 edition of Disraeli's works, The Works, ed. by Edmund Gosse, $x$.

47 B. Disraeli/Sarah, Letters, 271. Letter no. 622, London, 19 June 1837.

48 Moneypenny and Buckle, The Life, vol. 1, 287. 49 Weintraub, Disraeli, 16.

50 The examples are listed in Weintraub, Disraeli, 77-78.

51 Victoria to Leopold, King of Belgium, 30 March 1852. In, Arthur Christopher Benson, and Reginald Baliol Brett Esher, eds., The Letters of Queen Victoria: Selection from Her Majesty's Correspondence between the Years 1837 and 1861, 3 vols. (London: J. Murray, 1908), 386.

52 Weintraub, Disraeli, $111 . \quad{ }^{53}$ Feuchtwanger, Disraeli, 3; Weintraub, Disraeli, 115.

54 William Shakespeare, Henry IV, Part II, Act 1, Scene 2. Disraeli paraphrased Falstaff's line in a letter to Sir Stafford Northcote, 2 Sept. 1876. The letter is reprinted in Moneypenny and Buckle, The Life of Benjamin Disraeli, vol. 6, 57. 
duction to high society to Edward Bulwer. Bulwer (1803-1873) was the son of Gen. William Bulwer and Elizabeth Lytton, and assumed the name Bulwer-Lytton in 1843 when he inherited the Lytton estate, "Knebworth." He was well received both as a writer and as a socialite. In 1858 he was named Secretary of State for the Colonies. For his achievements as novelist, playwright, and statesman, he was elevated to the peerage in 1866 and was thereafter known as Baron Lytton of Knebworth. Disraeli met Bulwer in 1832 and they became the closest of friends. The love of both men for fanciful dress and posturing has even been interpreted to mean that the attraction between them was homoerotic. ${ }^{55}$

To Bulwer, Disraeli's exotic Jewishness was more of a draw than a drawback. His fascination with the East is a matter of record. At the age of seventeen, he penned a longish orientalist epic poem, entitled Ismael, an Oriental Tale. ${ }^{56}$ When Bulwer first met Disraeli the former's brother Henry was also present. Henry reported being extremely impressed not only with Disraeli's conversational skills but also his appearance. Disraeli's olive complexion, dark curls, and black eyes, so strikingly exotic to his contemporaries, fascinated him. If Disraeli's appearance appealed to Henry it might well have appealed to his brother; there is certainly no reason to think that Edward found "Dizzy's" oriental visage unattractive.

To say that Disraeli's romantic Semitism inspired passionate devotion among Gentiles would be a huge exaggeration. But it did make people take note of his "curious" persona. Paul Smith's brilliant short biography focuses on his overwhelming theatricality: Disraeli was a show. In an age of world fairs and illustrated magazines devoted largely to exotica- “commodity imperialism," Anne McClintock called it ${ }^{57}$ - it did not rub everyone the wrong way to have a leader who postured as a blend of three of the major dramatis personae of pulp imperialism: an English gentleman, a Hebrew prophet, and a sheik of Araby.

The truth is that Disraeli repelled some but attracted others. He was equally the inspiration for merciless parody and anti-Jewish diatribes by Anthony Trollop and of admiration and pro-Jewish narrative by George Eliot. ${ }^{58}$ Anti-Semitism is ingrained in the cultures of the West, yet in England at the time many people could relate to "Dizzy's" racial pride.

55 The point is made by Mark Booth, in Camp (London: Quartet Books, 1983), 107-8. See also Andrew Elfenbein, Byron and the Victorians (Cambridge and New York: Cambridge University Press, 1995), ch. 6: "The Shady Side of the Sword: Bulwer Lytton, Disraeli, Wilde, and Byron's Homosexuality."

56 It is true that Bulwer-Lytton's Leila, or the Seige of Granada (1838) continues anti-Jewish stereotypes while also celebrating a belle juive character; and that My Novel or Varieties of Life (1853) includes the avaricious assimilated Jew, Baron Levy. But Bulwer-Lytton always excuses the deficiencies of his Jewish characters by the exigencies of Jewish history.

57 Anne McClintock, Imperial Leather: Race, Gender and Sexuality in the Colonial Contest (New York: Routledge, 1995).

${ }^{58}$ For an excellent discussion that compares Trollop's and Eliot's views of Disraeli see Michael Ragussis, Figures of Conversion: The Jewish Question \& English National Identity (Durham, N.C.: Duke University Press, 1995), especially ch. 6. 


\section{RACE THINKING}

The public understood Disraeli's demonstrative Semitism because it was closely related to their own English jingoism. ${ }^{59}$ They understood the founding concept of both: "race." Disraeli's thinking on race is succinctly summarized in the confident declaration made in Tancred that "All is race; there is no other truth." 60 It is well known that in Disraeli's father's generation a low opinion of Jewish racial character was shared by the majority of Europeans, but was countered by some, mostly deists, who either ascribed Jewish defects to the environment or denied them altogether. Disraeli, who, like all nineteenth-century Jews, tried to dismantle the master's house with the master's tools, went a good bit further than these well-wishers. Not only did he deny the racial inferiority of the Jews, but he turned racism on its head and used it to affirm the superiority of the Jews, whom he called the "anointed race." $61 \mathrm{He}$, a Jew by race but not by religion, reinterpreted Sinai in racial terms: God's chosen people were a chosen race.

It would be anachronistic to equate Disraeli's race thinking with the vitriolic racism of the next two generations, but equally wrong to excuse his concept of a "race" as merely a synonym of "people" without the connotations of genetic immutability, of the odious transformation of a social construct into an artifact of nature. Disraeli even expressed the "scientific" opinion, so important in later racist thought including that of the Nazis, that racial mixture was harmful to the qualities of a people. When, in Coningsby, we are told that the Jews are the aristocracy of Nature, we are also told in the same breath that they are "unmixed" and "a pure race of the Caucasian organization."62

The mention of "Caucasian" is important. Disraeli favored Johann Friedrich Blumenbach's racial typology, which included both Aryans and Semites as "Caucasians." As Patrick Brantlinger put it, "Beyond the Anglo-Saxon's seemingly ancient racial roots, [Disraeli suggested,] lies an even older, more inclusive and influential, racial configuration. (. . .) In short, Disraeli accepted Anglo-Saxonist racial and nationalist categories only to supplement them through the claims of his pro-Semitism." 63 To put it another way, Disraeli located the cultural history of the Jewish race and that of the English race in the same narrative and imaginative context. It was at least partly a successful ploy, striking as it did a responsive cord among the Gentiles.

"First, Disraeli's trilogy [the novels Coningsby, Sibyl, and Tancred] was a direct response to a kind of discourse about race and culture already in place by the early 1840s; and second, the trilogy was to have a profound influence on one of the most famous representations of English culture later in the century,

\footnotetext{
59 The term "jingoism" comes from a popular song celebrating Disraeli's strong imperial policies.

60 Tancred, 176. 61 Tancred, 202. 62 Disraeli, Coningsby IV, xv; cf. Tancred, 461.

63 Brantlingner, "Disraeli and Orientalism," 99.
} 
Matthew Arnold's celebrated formulation of English national life."64 These words are from Michael Ragussis' magisterial work on the subject of the Jewish trope in nineteenth-century English identity. Ragussis makes it clear that Disraeli's glorification of the Jewish-English connection was far from the ambiguous association that Arnold and others proposed and, to a large extent, began to abandon under the impact of Aryanism. But, since Disraeli was in full concert with the dominant Western attitudes of his time on the role of race in national life, he could at least expect, and was given, a serious hearing.

The development of modern nationalism accompanied, as is well known, the rise of the mature bourgeois class. ${ }^{65}$ The concept of race helped to make the "imagined community" of the nation appear as a product of nature rather than an artifact of society. Roland Barthes termed such a process of "naturalizing" social constructs a "myth." Myths, he insisted, "distorted" social facts in the service of the powerful: they "mythologized" social inequality as part of nature. The myth of the nation presented it not as the construct of bourgeois ascendancy, but as the natural result of "race."

It was not surprising that racial distinction should, in Disraeli's fiction, be best exemplified by a bourgeois character: the "wise banker." In the so-called Young England novels (the trilogy mentioned by Ragussis), Disraeli expresses his most deeply felt political, moral, and religious views through the words of two Jewish bankers, the mysterious millionaire Sidonia and a Middle Eastern colleague called Besso. One man's banker, of course, easily becomes another man's usurer, or, in this case, rather the other way around. Disraeli has, in his banker-philosophers, taken the stereotype of the Jewish money-lender and turned it around to create the image of a wise dispenser of wisdom.

Disraeli's novels were often entirely or in part romans a clef, and there was lively speculation as to whom his characters represented. Disraeli must have been pleased to see his philosopher-bankers identified with the Rothschilds, as would have been the Rothschilds themselves. The Rothschilds, however, were never philosophers enough to provide the model for Besso or Sidonia. The real model was closer to Nathan the Wise, the philosophical Jewish banker in Gotthold Lessing's eponymous play, than to Nathan Rothschild.

Lessing's play of 1779 excited audiences by its deist conviction that nonChristians were equal partners to Christians in theological and philosophical debates. The main protagonists include Saladin, the famed Muslim "sultan," Conrade, a young Christian pilgrim, and Nathan, a Jewish caravan-owner and financier. As the title indicates, Nathan is the wisest of the three. Lessing's Nathan the Wise provided not only vital monetary support to Saladin, but also moral and religious advice. Disraeli's bankers play the same role. There are other similarities. Like Conrade in Nathan, in Tancred, too, it is a young Christian

${ }^{64}$ Ragussis, Figures of Conversion, 211.

65 As an example see David Cannadine, The Rise and Fall of Class in Britain (New York: Columbia University Press, 1999). 
pilgrim that represents Christian Europe, and in both cases is less eager to preach to than to learn from his oriental hosts.

Lessing's work became immensely popular among modernizing Jews longing to be respected by Gentiles. In Germany, it remained down to the advent of Hitler an icon of German philo-Semitism and as such an important fixture in the ideology of Jewish Deutschtum. Although there is no direct evidence that Disraeli knew Lessing's philo-Semitic classic, there are a number of reasons why it is likely that he was influenced by it. For one thing, there was at the time a vogue in England for German culture: among the writers who like Coleridge derived inspiration from German thought was Disraeli's friend Bulwer-Lytton. ${ }^{66}$ Disraeli's' connections to continental sentiments have recently been rightly rescued from oblivion by writers such as Paul Smith, who feels that "[o]bserved in the wider setting of European romanticism, what in the English context appears outlandish and bizarre becomes normal, and even, in some aspects, banal: the aberrant becomes conventional. 'My mind is a continental mind,' Disraeli wrote in the so-called 'Mutilated Diary' in 1833."67

Though Lessing was perhaps not a romantic, he was an essential element in the romantic Jewish Semitism which, though perhaps still odd in an English Jew, was hardly "outlandish and bizarre" on the continent. Furthermore, Disraeli spent time working in a Jewish law office in Holland, where Jews maintained even stronger links with their German coreligionists than did English Jews. Finally, Disraeli's father had a large library and was quite interested in Jewish issues, and it is probable that he owned or at least had heard of Lessing's work. At any rate, by glorifying Jew and banker in one go, Disraeli was true to his purpose of improving the reputation of the Jewish race by appealing to the ascendant British bourgeoisie.

\section{TORY DEMOCRACY}

The process, possibly incomplete, whereby the bourgeoisie displaced the aristocracy as ruling class was not necessarily always a class struggle. The highsociety novel such as Jane Austen's Pride and Prejudice or Mansfield Park imagined aristocrats readily mingling with rich bourgeois as equals, or just about. All of Disraeli's novels included this feature, although only some, such as Vivian Grey or Henrietta Temple, were genuine high-society novels. They express, not a desire to eliminate the principle and privileges of the aristocracy, but a wish to see that at least some bourgeois are able to share them.

As a class, the bourgeois for the most part tended to oppose aristocratic privilege, though exceptions were particularly common in England. However, as individuals, many if not most craved the same level of distinction that has been accorded to the nobility. Becoming a peer was the most cherished dream of

\footnotetext{
66 Rosemary Ashton, The German Idea: Four English Writers and the Reception of German Thought 1800-1860 (Cambridge, UK: Cambridge University Press, 1980).

67 Smith, Disraeli, 15. Gunn, et al., Letters, vol. 1, 447.
} 
many a bourgeois millionaire: the Rothschilds fought fanatically — and paid handsomely - for the privilege to be named Barons in Austria.

For those who could not hope to become lords and ladies, "race thinking" was a consolation prize that still offered some distinction of birth. To surround themselves with the aura of pedigree, the bourgeois encircled themselves with old art and antique furniture. The fascination with descent also led to serious progress in animal husbandry, dog breeding, dove raring, and oenology. As ladies and gentlemen bred animals and improved plants, they practiced on their surroundings the doctrine of race as nobility.

"Oriental race" was associated with a certain veneer of exotic nobility in part because of its place in horse breeding. (According to the official General Stud Book all the thoroughbreds of the world are descended in direct male line from one of three oriental ancestors: a Turkish horse named Byerly, the Arabian Darley, and an animal named Godolphin, taken to England from Paris, which was either an Arabian or a "barb" (from Barbary).

The concept of a "noble race" in the animal kingdom grew as part of the effort to find noble and not-so-noble races among humans. Nineteenth-century nationalists claimed nobility for their own nation. Disraeli, who shared with other Englishmen the conviction that the English were a most noble race, wanted them to believe that the Jews, as orientals, were a noble race also.

It is wrong to conclude from Disraeli's lack of enthusiasm for Greek and Slavic nationalists (to which I will return) that he was, as Robert Blake put it, "totally unsympathetic to the spirit of nationalism which was the dominating force in his time." 68 On the contrary, the spirit of nationalism at the time was a racial spirit; Ragussis even made the radical suggestion that the extermination of inferior races "was central to the conception of the origins of the nation-state that was being worked out in the first half of the nineteenth century."69 Disraeli's "race thinking" fits well into this context. He made Fakredeen, the oriental potentate in Tancred, exclaim that ". . . nationality, without race as a plea, is like the smoke of this nagrilly, a fragrant puff."70 "Race thinking" was one of the foundations of Disraeli's populist politics, known under the heading of "Tory democracy." This was not as much a version of democracy as an alternative to it.

As a contemporary put it, Disraeli always stuck to the distinction between "popular privileges and democratic rights."71 If Disraeli spoke up for the right of Jews to sit in Parliament — as he did courageously in 1847 when he was still

68 Robert Blake, Disraeli's Grand Tour: Benjamin Disraeli and the Holy Land, 1830-31 (London: Widenfeld and Nicolson, 1982), 31. Feuchtwanger is of a similar opinion ("Jew Feelings," 188), but Brantlinger differs ("Disraeli and Orientalism," 95-96).

69 Ragussis, Figures of Conversion, 261. It was only later that, as Hannah Arendt showed, the racism of the "pan-movements" became the enemy of the nation-state.

70 Tancred, 306.

71 Thomas Edward Kebbel, Lord Beaconsfield and Other Tory Memories (London: Cassel, 1908), 254. 
a rookie Member, in opposition to his own Tory party - he emphatically "dismissed" the relevance of "the principle of religious liberty . . . that you should not look to faith, but admit all faiths alike." Rather, he argued that Jews should be let in because of their special, distinctive merits as a people who gifted to Christians "that literature which for thousands of years has brought so much instruction and so much consolation to the sons of men." 72

Similarly, his campaign for extending voting rights to many (but not all) members of the working class was not based on the belief either that all men were created equal or that all men shall be brothers, but that the noble race of Englishmen possessed distinctive qualities that entitled all decent members of the nation to have a voice in government. The "dream of my life," wrote Disraeli, was "re-establishing Toryism on a national foundation." $" 73$ Disraeli trusted working class Englishmen to work together with the more privileged classes to create a society where people were united not as equals but as sharers in the greatness of their nation. Ann Potinger Saab rightly pointed out that Disraeli's Conservativism was the radical conservativism of self-made men like Napoleon III (and to a lesser degree Bismarck) who reached out to new classes."74 What Disraeli offered to new classes was inclusion with the old ones, on the principle of race.

In 1867, Disraeli (who was then a Tory minister) led a campaign that outmaneuvered the opposition Whigs and made the Tories the first party to institute an electoral system that was essentially based on the principle of "household suffrage." For the first time, Britain came close to full democracy. True, as soon as an election under the new rules was organized, the ungrateful voters turfed Disraeli and his party out. But the root idea of Tory Democracy, which extended the trope of the noble family to that of the imagined community of a noble nation, was to endure and to find powerful expression in the language of Empire.

\section{A COMMONWEALTH OF ASSOCIATION}

The character of Disraeli's imperialism was not only consistent from one speech and action to another. It also fit in perfectly with, first, his Jewish racial pride and second, his concept of "Tory democracy." All three-his imperial thoughts and policies, his Jewish pride, and his brand of quasi-democracywere knit together with considerable consistency by the common thread of his idiosyncratic Jewish-English brand of orientalism.

The dream of Tancred was to establish an Empire of East and West guided by English practical sense and the inspiration of oriental religious wisdom. Disraeli's insistence that his oriental race was a worthy partner to the English conditioned his conception of the Empire as a "new social system, which was to

72 Hansard, Debates, 16 Dec. 1847, 1327 and 1329.

73 Moneypenny and Buckle, The Life, vol. 4, 552-53. 74 Saab, "Foreign Affairs," 310. 
substitute the principle of association for that of dependence as the foundation of the Commonwealth, under the sanction and superintendence of the God of Sinai and of Calvary." 75

That Mecca is omitted is as much as one needs to show that Disraeli's "East" was for the most part the typical orientalist fantasy of a nineteenth-century European, who appropriated the right to determine what is best for the "orientals" without seriously considering their own thoughts and wishes. And of course Disraeli was an imperialist who never for a moment doubted England's right to rule over oriental "natives." Nevertheless, his "East" was at least as important a part of his ideal Empire as the West. In 1866 he declared that, "England is no longer a mere European power; she is the metropolis of a great maritime empire, extending to the boundaries of the farthest oceans ... she interferes in Asia, because she is really more an Asiatic power than a European." 76

In an 1876 article in The Times, Disraeli praised ". . . the unexampled Empire which [England] has built up and which it is her pride to remember exists as much on sympathy as on force." 77 Force was taken for granted by Disraeli the imperialist. But what Disraeli the romantic orientalist meant to stress was "sympathy." As far as he was concerned, the ideal British Empire gave an opportunity to compliant orientals to participate proudly and actively in a commonwealth that meets with their assent, on the model perhaps of Disraeli himself, who rose to the top of imperial power in spite of his "oriental race."

As was often the case with pro-oriental imperialists, Disraeli expressed his affection for the oriental "races" in class terms as solidarity with their ruling classes - a privileging of class over race. He berated Europeans who, "when they can wring no more from their peasants, ... plunder the kings of India." $" 78$ Here he was protesting not only colonial exploitation but perhaps even more so the idea that kings should be treated as peasants just because they are Indian kings. The kings of India, it is true, are not being encouraged to think of themselves as the equals of the English queen, but they could in Disraeli's view expect the kind of respect that a king gives to his chivalrous retainers (or a breeder to his beloved Arabians?). The possibility of an oriental being of a superior class was of course of considerable personal importance to Disraeli.

Not all orientals, in other words, were created equal. Indeed, although Disraeli was undoubtedly sincere about the Empire as a commonwealth of association, he did not feel equally enthusiastic about all of its "races." His imperial policies appear to have reflected a pecking order where Muslims came before Christians, Semitic Muslims before non-Semitic ones, and Jewish Semites before Arabs.

Despite his immense fascination with Byron, the youthful Disraeli had been,

75 Tancred, 437-38.

76 The Times, 14 July 1866. See also F. Harcourt, "Disraeli’s Imperialism, 1866-1868: A Question of Timing," Historical Journal 23 (1980), 96.

77 The Times, 10 Nov. 1876.78 Tancred, 287. 
along with Bulwer-Lytton, among the few lonely dandies who strongly favored the Muslim Turks against the Christian Greeks in the latter's war of independence. We have seen earlier how he noted his delight with having smoked a sixfoot chibouk with a Turkish "pacha" fighting the Greeks. At the end of the passage he added, "... I detest the Greeks more than ever."

Decades later, when he was prime minister of the realm, Disraeli's pro-Turkish sentiments showed themselves with renewed force. In 1875, groups of Russian-backed Slavic peasants on the Balkan Peninsula rose against Turkish rule. Western correspondents brought news of awful Turkish atrocities. Newspapers reported on rebels impaled through the anus, left to slowly sink onto the stake and to die in terrible agony several hours or even days later.

This report of bloodthirsty "oriental cruelty" intolerably combined unspoken references to the Crucifixion and sodomy. It kept England in shock for months. Crowds protested against Disraeli's dismissive reaction, for he claimed at first that the reports of atrocities were exaggerated, and steadfastly rejected support for the Christian rebels. The protest was very much a mass movement in the modern sense, relying on shocking media reports and large political gatherings. A National Convention held on the issue received letters of support from Carlyle, Browning, Darwin, and Herbert Spencer. ${ }^{79}$

Disraeli's arch-enemy, Gladstone, was of the opinion that "Dizzy's cryptoJudaism has had much to do with his policy. The Jews of the East bitterly hate the Christians; who have not always used them well." The opposite, however, was asserted by Moneypenny and Buckle, who held that "[t]here is no trace of Beaconsfield's specially Jewish feeling in his Eastern policy." ${ }^{80}$ Recently the argument against a Gladstonian interpretation of Disraeli's motivations was developed by Edgar Feuchtwanger, who believes, with reference to Disraeli's handling of the Balkans issue, that, "Jewishness may have been important in Disraeli's personality and self-understanding, though it remains difficult to separate it from his sheer love of romance and mystification, but he did not allow it to influence him as a politician." 81

Feuchtwanger is quite right that British support for Turkey had long been the cornerstone of British policy, because an overly weak Turkey could come under the sway of Britain's imperialist rival, Russia. But could Disraeli not have been a British Realpolitiker and a Jewish fantaisiste at the same time? That he acted in accordance with what some saw as British interests need not exclude his romantic Jewish orientalism as an additional motivator.

The real question is whether Disraeli was prepared to act on his Jewish proorientalism even in preference to British interests. We need a test case in which

79 See Robert W. Seton-Watson, Disraeli, Gladstone, and the Eastern Question; A Study in Diplomacy and Party Politics (London: F. Cass, 1962), 110.

80 According to Moneypenny and Buckle, Gladstone made his statement to the Duke of Argyll (The Life of Benjamin Disraeli, vol. 6, 58).

81 Edgar Feuchtwanger, "Jew Feelings," 195. 
British interests could not be said to coincide obviously with Disraeli's romantic pro-Semitism. Perhaps the closest to such a case was the episode of the Muhammad Ali rebellion in Egypt. The young Disraeli (who was not yet a leading politician and was therefore not constrained, it is true, by the dictates of realistic policy) had stood opposed to what almost everyone considered in the British interest, and supported the cause of the Egyptian ruler Muhammad Ali (1769-1849) against the Ottoman Turkish sultan.

\section{MUHAMMAD ALI}

As one of the proofs for his position, Feuchtwanger takes from Moneypenny and Buckle a Disraeli quote: “. . . all the Turks may be in the Propontis, so far as I am concerned." It might have been more to the point to note Moneypenny and Buckle's judgment that "The race which [Disraeli's Jewish feelings] would have led him to support would have been, as was shown in Tancred, the Arab, and not the Turk." 82 In the Balkan uprising Disraeli was dealing with the Turk, not the Arab. In the Muhammad Ali rebellion, he supported the Arab against the Turk.

Muhammad Ali, also known by the Turkish version of his name, Mehemet Ali, was actually an Albanian from Macedonia. It is not clear if Disraeli knew this, but as we shall soon see he did in Tancred imagine him at the head of a "Bedouin cavalry." In the 1830's he was Egypt's viceroy or khedive, and as such though nominally under Ottoman control was de facto the ruler of the land. In addition to acquiring effective independence from Istanbul he even managed to gain a solid foothold in West Asia, including Palestine. He might have moved on to Istanbul itself had decisive British intervention under Palmerston, exemplified by the Royal Navy's involvement at Acre in 1840, not saved the Porte form his designs.

If Disraeli's one guiding principle was, as it had been for Palmerston, the defense of an Ottoman Empire strong enough to stand up to Russia (and to oppose the French, who supported Muhammad Ali), then his siding with Muhammad Ali is difficult to understand. The only thing that can explain why he deviated from his support of Ottoman Turkey in the case of Muhammad Ali is the nature of his own "oriental" and Jewish sentiments: He defended oriental Turkey against Christian Greeks and Russians, but not against his fellow Semites, the Arabs. His sympathies were made quite clear by the Arab emir Fakredeen in Tancred: "The peninsula of Arabia, when in action, must always command the peninsula of Lesser Asia [Turkey]." 83

We know that Disraeli dreamed of a Semitic link towards India in the Southern and Eastern Mediterranean, forging an alliance of Englishmen and Semites that would literally make a connection between East and West.

Such a plan is explicitly outlined in Tancred. In the novel the Arab emir

82 Feuchtwanger, "Jew Feelings," 188, quoting Moneypenny and Buckle, The Life of Benjamin Disraeli, vol. 2, 925; “Arab, and Not the Turk," vol. 6, 58.

83 Tancred, 312-13. 
Fakredeen holds forth on his vision of a British-led empire focused on Asia and supported by Arabs:

Let the Queen of the English collect a great fleet, let her stow away all her treasure, bullion, gold plate, and precious stones: be accompanied by all her court and chief people, and transfer the seat of her empire from London to Delhi. There she will find an immense empire ready made, a first-rate army, and a large revenue. In the mean time I will arrange with Mehemet Ali. He shall have Bagdad and Mesopotamia, and pour the Bedoueen cavalry into Persia. I will take care of Syria and Asia Minor. The only way to manage the Affghans is by Persia and by the Arabs. We will acknowledge the Empress of India as our suzerain, and secure for her the Levantine coast. If she like, she shall have Alexandria as she now has Malta: it could be arranged. ${ }^{84}$

The Arab Bedouin were to be the military element holding together the great Empire with England and India at its opposite poles through their military might. But the Empire's spiritual cement would be another nation of Semites, those among whom the "spirit of Calvary" originated.

Disraeli seems to have known that the English-Jewish philanthropist and early Zionist Moses Montefiore, on his visits with Muhammad Ali in 1837 and 1838, proposed to the latter a scheme for Jewish settlement in Palestine and that Muhammad Ali was at least willing to listen. In Tancred, Disraeli gives the impression that he thought Muhammad Ali was in favor. In that book the Middle Eastern Jewish banker Besso holds forth about the remarkable number of statesmen of "Hebrew descent" in "modern times." Improbably, he included even the Prime Minister of Egypt Artim Bey (Disraeli thought Mozart was of Jewish descent as well). ${ }^{85}$ Thoroughly impressed, Tancred exclaims, "It seems to me that you govern every land except your own," meaning, of course, Palestine. To which Besso responds, "That might have been done in '39"; that is, if Muhammad Ali had succeeded. ${ }^{86}$

It might be objected that such were the foibles of a youthful mind unencumbered by the duties of office. But, as Paul Smith argues, we must guard against the unsubstantiated "chopping of Disraeli into two intellectually unconnected or inconsistent halves, the young swashbuckler and the mature, pragmatic leader. . . . It tends to deprive Disraeli of a consistency of outlook and wholeness of political conception which it was, throughout his life, one of his central aims to assert." 87

Disraeli's appraisal of the Muhammad Ali episode shows how his political analysis was aimed towards realizing his orientalist visions of Jewish glory. Later he was able to give the "dream" a political shape. We saw this in the grounds on which he supported, in 1847, admitting unconverted Jews into Parliament. Another example is provided by his interventions on India.

${ }^{84}$ Tancred, 270-71.

85 On Mozart see: Benjamin Disraeli, Lord George Bentinck: A Political Biography (London: Longmans, Green and Co., 1881), 354.

86 Tancred, 408.87 Smith, Disraeli, 5. 


\section{THE EMPRESS OF INDIA}

A united Semitic Orient would not, for Disraeli, be an end in itself for the Empire of East and West. In Fakredeen's scheme its role is above all to be the central foundation upon which its most important elements, England in the West and India in the East, rest. Among the many things Disraeli and Victoria had in common was their romantic regard for India as the "jewel of the crown." Disraeli was prepared to stick his neck out against the cruelest abuses of colonial rule there. During the Indian Mutiny of 1857, his voice was quite lonely in Parliament as he voiced sympathy with the Indians' grievances. He suggested that Britain could only conquer India "in the same sense in which William of Orange conquered England;" that is, as liberators from "tyranny" and protectors of the native population's religion and property ${ }^{88}$ And he concluded, to general derision in his parliamentary audience, by suggesting an inquiry into the causes of the Indians' unhappiness.

He proved his regard for the Indians again when he used Indian troops to put down a revolt in Malta in 1878. It was perhaps the first time that a force of mainly "colored" soldiers were used against white enemies. It is true that from hindsight the measure was a perfectly selfish one, but it was roundly condemned by many on racial grounds. Disraeli's hostile biographer T. P. O'Connor condemned it in the context of the Disraeli government supporting the Muslim Turks against Europe's Christian Slavs, and used it to defend his picture of Disraeli as "our Oriental dictator." 89

Just how important India was to Disraeli is shown by the mother of the hero in Disraeli's largely autobiographical novel, Endymion. "I am not sure," she exclaims, "whether I would not prefer being Governor-General of India even to being Prime Minister." 90

As it turned out, Disraeli never became Governor-General of India. Nor did the Queen move herself and her bullion, as Fakredeen suggested, to New Delhi. However, symbols did count for something, to both Britons and Indians, and Disraeli helped, more than anyone else, to orchestrate an act of great symbolic power for the "Commonwealth of Association": the crowning of Victoria as Empress of India. As Paul Smith points out, there were non-imperial reasons, including the Queen's desire to have the imperial title to match that of other European rulers. ${ }^{91}$ But Disraeli's friends and enemies both saw the coronation as an expression of his romantic orientalism. The sentiment is nowhere better illustrated than in the well-known cartoon from Punch showing a slyly beguiling, turbaned Disraeli offering a crown in the shape of an oriental dome to a reserved Victoria, in exchange for the English crown she holds in her hands.

\footnotetext{
88 Hansard record, Debates, 27 July 1857.

89 Thomas Power O'Connor, Lord Beaconsfield: A Biography (London: T. Fisher Unwin, 8th ed., 1905), 663.

90 Benjamin Disraeli, Endimyon (London: Longmans Green, 1880), vol. 1, 82-83.

91 Paul Smith, Disraeli, 199-200.
} 
The preparations for the crowning took place under Disraeli's remote control. Field Marshall Lord Roberts recalled how for days before the ceremony Indian dignitaries and their retinues were arriving in large numbers:

The magnificence of the native princes' retinues can hardly be described; their elephanthousings were of cloth of gold, or scarlet-and-blue cloths embroidered in gold and silver. The howdahs were veritable thrones of the precious metals, shaded by the most brilliant canopies, and the war-elephants belonging to some of the Central India and Rajputana chiefs formed a very curious and interesting feature. (...) Delhi must have witnessed many splendid pageants, when the Rajput, the Moghul, and the Mahratta dynasties, each in its turn, was at the height of its glory; but never before had princes and chiefs of every race and creed come from all parts of Hindustan, vying with each other as to the magnificence of their entourage, and met together with the same object, that of acknowledging and doing homage to one supreme ruler. ${ }^{92}$

The Field Marshal's biblically inspired prose only heightens the unconscious but effective association of the "one supreme ruler," the Queen now become Empress, with the Christian God.

On New Year's Day, 1877, the viceroy and his lady finally appeared atop what was said to be the largest elephant in India, riding in a silver howdah. The animal tottered on, then allowed its riders to be helped to the ground. The viceroy, a Disraeli appointee, was Edward Robert Lord Bulwer-Lytton, the son of the very author with orientalist sympathies who made Disraeli's social ascent possible. Lord Lytton ascended the imperial throne, and the band broke out with the chords of Beethoven. ${ }^{93}$ In this setting, the music unmistakably symbolized the imagined role of the European sovereign as a foreign protector (a father, Anne McClintock would say - is this why the Great White Mother was here represented by a man?), ${ }^{94}$ set over, and legitimating, the chiefs of oriental tribes.

This very British vision, depicting the West as guarding over local "racial" traditions, owed quite a bit to Disraeli's enthusiasms. We, of course, know how ruthlessly self-serving such colonial "protection" was, and so in many ways did the colonizers in London, with Disraeli at their head. Yet the Earl of Beaconsfield was not completely insincere. He did believe that East and West could achieve a harmonious union under British auspices and with the Semitic spirit as its spiritual cement. As he saw it, he represented such a union in himself.

92 Eva March Tappan, ed., The World's Story: A History of the World in Story, Song and Art, Vol. II: India, Persia, Mesopotamia, and Palestine (Boston: Houghton Mifflin, 1914), 184-90.

93 Bernard S. Cohn, "Representing Authority in Victorian India," in, Eric Hobsbawm and Terence Ranger, eds., The Invention of Tradition (Cambridge: Cambridge University Press, 1992), $165-209$.

94 McClintock, Imperial Leather. 